on leave during 1967-68. He will do research in Moscow and Leningrad under an Inter-University Committee Travel grant.

Robert Thompson, Sacramento State College, was on sabbatical leave, spring term, 1967.

Peter A. Toma, University of Arizona, spent the summer in research in Hungary under an Inter-University Committee Travel grant.

John E. Turner and Robert HolT, University of Minnesota, attended the Conference on Mediterranean Development, sponsored by the Institute of Man and Science, held in Tunis, Tunisia, March 17-April 2, 1967.

JACK L. WALkER, University of Michigan, will be on leave during 1967-68.

Meredith W. Watts, JR., University of Wisconsin-Milwaukee, will be on leave, 1967-68.

Brron S. Weng, Wright State campus of Miami and Ohio State Universities, has been awarded a grant by the Regional Council for International Studies to travel and do research in Taiwan. He spent the summer in Taiwan.

\section{Staff Changes}

\section{New Appointments}

JoEL ABErBach, assistant professor, University of Michigan.

EMILE B. ADER, professor, University of Arkansas.

Victor Alba, lecturer, Kent State University.

Benedict R. Anderson, assistant professor, Cornell University.

Jean Douglas Andrew, assistant professor, University of Maine/Augusta.

Thomas Anton, associate professor, University of Michigan.

E. Ramon Arango, associate professor, Louisiana State University; formerly of Kenyon College.

Robert J. ARt, assistant professor, Brandeis University; formerly of the Kennedy Institute at Harvard University.

Robert L. Arres, acting assistant professor, University of California/Berkeley.

Rrchand BALKEMA, assistant professor, Valparaiso University.

Edaene Bardach, assistant professor, Branturned from a leave of absence in Malaysia.

AnN Ruth Wiluner, Center of International Studies, Princeton University, spent the spring and summer in Indonesia and Africa. She has been awarded grants by the Rockefeller Foundation and the American Council for Learned Societies.

Clifton E. Wilson, University of Arizona, will be on sabbatical leave, 1967-68.

Desmond P. Wilson, formerly of Emory University, has joined the professional staff of the Center for Naval Analyses.

JAmes S. Young, Columbia University, received a 1967 Bancroft prize for his book, The Washington Community, 1800-1828.

George T. YU, University of Illinois, Urbana, has been awarded an SSRC grant for 1967-68.

Aristide Zolberg, University of Chicago, will be on leave from January-August, 1968 to do research in Western Europe. He has an SSRC grant.
Lea E. Williams, Brown University, has re-

deis University; formerly of University of California/Berkeley.

Weldon V. Barton, assistant professor, Texas Technological College.

Thomas J. Bellows, assistant professor, University of Arkansas; formerly of Yale University.

Francis Beer, assistant professor, University of Texas, September 1967.

Ruth A. Bevan, instructor, Yeshiva University.

Thad Beyle, assistant professor, University of North Carolina.

JAMEs BILL, assistant professor, University of Texas, February 1968.

William Bishop, assistant professor, Denison University; formerly of Northwestern University.

WINFIELD S. BoLLINGER, assistant professor, University of Toledo.

JAMES BoLNER, associate professor, Louisiana State University; formerly of the University of Massachusetts.

Gaylor Matthew Bonham, assistant professor, University of California/Berkeley; formerly 
of the Norwegian Institute of International Affairs.

STEveN J. Brams, assistant professor, Syracuse University.

Bernard Brodie, professor, University of California/Los Angeles; formerly of Rand Corporation.

STeVen BRown, assistant professor, Kent State University.

Jere BRUNer, assistant professor, Oberlin College; formerly of Yale University.

Coralie BRyant, assistant professor (half +ime), School of Government and Public Administration, American University.

EMORY Bundy, assistant professor, Oberlin College; formerly of the University of California/ Los Angeles.

JAMES D. L. Byrnes, assistant professor, Emory University; formerly of University of Maryland.

Larry Caldwell, assistant, Occidental College; formerly of Wellesley College.

Blair Campbelu, assistant professor, University of California/Los Angeles.

Lours Cantori, assistant professor, University of California/Los Angeles.

Eric Carlson, Instructor, University of $\mathrm{Ne}-$ braska.

Gregory Caser, assistant professor, University of Missouri; formerly of Trinity College, Washington, D.C.

Douglas Chaffer, assistant professor, University of Montana.

Samuel G. Chapman, professor, University of Oklahoma.

Hsi-Sheng ChI, assistant professor, University of North Carolina; formerly of University of Chicago.

Dotgglas A. Chalmers, associate professor, Columbia University.

JAMEs R. CobBledick, assistant professor, Trinity College/Hartford, Connecticut; formerly of Skidmore College.

Terrence E. Cook, instructor, Washington State University; formerly of Princeton.

Cornelius Cotter, professor, University of Wisconsin-Milwaukee; formerly of Wichita State University.
Anthony R. C. de Crespignt, associate professor, Western Reserve University; formerly of Monash University, Australia.

Robert E. CRew, assistant professor, University of Minnesota.

Meluin Croan, associate professor, University of Wisconsin; formerly of Harvard University, September 1967.

Richard W. Crosby, assistant professor, Emory University; formerly of Cornell University.

Adrian Crutrwell-Vaughn, instructor, Wheaton College.

Joe B. Darnall, assistant professor, Iowa State University.

Jorge A. Capriata D'Auro, assistant professor, University of California/Berkeley.

J. Clarence Davies, assistant professor, Princeton.

Paul DAwson, assistant professor, Oberlin College; formerly of Michigan State University.

Charles Dechert, professor, The Catholic University of America.

Alfred Diamant, professor, Indiana University; formerly of Haverford College.

Dennis D. Dorin, assistant professor, School of Government and Public Administration, American University.

LrLe A. Downing, assistant professor, Louisiana State University/New Orleans; formerly of Emory University.

LEwIS J. EDINGER, professor and research associate in the European Institute, Columbia University; formerly of Washington University, St. Louis.

Robert V. EdINGToN, instructor, University of Nevada.

James Eisenstein, assistant professor, University of Michigan.

James L. Elston, instructor, University of Arkansas; formerly of Princeton, September 1967.

RoBert B. Exestone, assistant professor, University of Minnesota.

Salo Engel, professor, Louisiana State University; formerly of the University of Tennessee.

AdA W. Finifrer, assistant professor, Michigan State University. 
David P. FLINT, instructor, University of Idaho, 1967-68.

R. Bоoтh Fowler, assistant professor, University of Wisconsin.

Dovglas Fox, instructor, Bowdoin College.

Edward I. Friedland, assistant professor, SUNY at Stony Brook.

Edward Friedman, assistant professor, University of Wisconsin.

Richard B. Friedman, assistant professor, SUNY/Buffalo; formerly of University of Pittsburgh.

Wayne L. Francis, associate professor, University of Washington; formerly of Syracuse University.

Joseph Fremanan III, assistant professor, Emory University; formerly of University of Virginia.

John GARGAN, assistant professor, Kent State University.

Robert Gerstein, assistant professor, University of California/Los Angeles; formerly of University of Minnesota, September 1967.

Vernon M. Goetcheus, Columbia College.

LouIs GoLd, instructor, University of Illinois/ Urbana.

EdWard Gonzalez, lecturer, University of California/Los Angeles; formerly of Wellesley College.

Jean Graham, adjunct professor, University of Denver.

A. James Gregor, acting associate professor, University of California/Berkeley; formerly of University of Kentucky/Lexington.

Frederick W. Grupp, assistant professor, Louisiana State University; formerly of University of Wisconsin/Racine.

IsobIL Gruhn, assistant professor, Oberlin College; formerly of University of California/ Berkeley.

Ted GURr, assistant professor, Princeton University; formerly research associate, Center of International Studies, Princeton.

Charles B. Hagan, professor, University of Houston; formerly of University of Illinois/ Champaign-Urbana.

Donald W. HaNson, assistant professor, University of Wisconsin.
Robert Hardgrave, assistant professor, University of Texas; formerly of Oberlin College.

B. Douglas Harman, assistant professor, School of Government and Public Administration, The American University. He will be associated also with The Washington Center for Metropolitan Studies.

FRed M. HAYWARD, assistant professor, University of Wisconsin.

NANCY W. HeER, instructor, Wellesley College.

Arnold J. Heidenheimer, professor, Washington University; formerly of University of Florida.

Richard H. Heinder, dean of the faculty and professor, Capitol Campus, Pennsylvania State University; formerly president of Pratt Institute.

Gerald J. Hewitt, assistant professor, Whittier College; formerly of Kent State University.

Marvin Hoffenberg, professor in residence, University of California/Los Angeles; formerly of the Institute of Industrial Relations, UCLA.

Richard I. Hofferbert, assistant professor, Cornell University; formerly of Williams College.

Joseph C. Honan, assistant professor, Sacramento State College; formerly of University of Wisconsin/Kenosha.

Michael J. Horan. assistant professor, University of Wyoming.

JACK W. Hopkins, assistant professor, Emory University; formerly of Georgia State College.

J. WoOdFord Howard, associate professor, Johns Hopkins University.

J. Paul Johnston, assistant professor, University of Alberta.

ZilLUR $\mathrm{K}_{\mathrm{AHN}}$, assistant professor, Wisconsin State University/Oshkosh; formerly of Sonoma State College.

Tetsuya Kataoka, assistant professor, State University of New York/Buffalo; formerly of Vassar College.

Gerald E. Kearns, assistant professor, University of Dayton; formerly of Wayne State University.

Hong N. KIM, assistant professor, West Virginia University.

George L. Krapt, assistant professor, Washington University; formerly of University of Michigan. 
Richard Landry, instructor, Cornell University, 1967-68.

Ruth A. Lane, assistant professor, School of Government and Public Administration, The American University.

Michael A. Leiserson, assistant professor, University of California/Berkeley.

Charles F. Levine, instructor, SUNY at Stony Brook.

John M. Lewis, instructor, Cornell University.

Charles Liebman, associate professor, Yeshiva University.

JAmes W. LindeEn, assistant professor, University of Toledo.

Shirley A. Lindeen, instructor, University of Toledo.

Geneviene Linebarger, associate professor, Trinity College, Washington, D.C.

RoBERT LINEBERRY, assistant professor, University of Texas; formerly of University of North Carolina.

Noah Lucas, lecturer, Sheffield University, Great Britain, October, 1967; formerly visiting lecturer, Glasgow University.

William A. Lucas, assistant professor, SUNY at Buffalo; formerly of Ohio State University.

Stuart A. MacKown, assistant professor, University of Wyoming; formerly of Washington College.

EDWARd S. MAKEcki, JR., assistant professor, California State College/Los Angeles; formerly of University of Illinois.

Vincent Marando, lecturer, University of Arizona; formerly of Michigan State University.

Theodore R. Marmor, assistant professor, University of Wisconsin.

Georae J. Mauer, associate professor, Drake University; formerly of Oklahoma State University.

Marvin Maurer, assistant professor, Louisiana State University; formerly of University of Southwestern Louisiana.

Charles G. Mayo, assistant professor and associate dean of the graduate school, University of Southern California.

Joel Patrick McBride, assistant professor, Sacramento State College; formerly of UCLA.
STEven MCCARL, assistant professor, University of Denver.

J. Peter Meekison, assistant professor, University of Alberta; formerly of University of Washington.

Richard Merelman, assistant professor, University of California/Los Angeles; formerly of Wesleyan University.

Patrick M. Morgan, instructor, Washington State University; formerly of Yale University.

Jeremiah MURPhy, instructor, Wheaton College.

Terry W. NARdiN, assistant professor, SUNY at Buffalo; formerly of Northwestern University.

JACK Noragon, instructor, Denison University.

JEFFREY OBLER, assistant professor, University of North Carolina/Chapel Hill.

Victor Olorunsola, assistant professor, Iowa State University; formerly of San Jose State College.

Barbara C. Osakwe, assistant professor, California State College/Los Angeles; formerly of Mt. St. Mary's College.

JAMES S. PACY, assistant professor, University of Vermont; formerly of Westminster College.

Arvin Palmer, lecturer, Whittier College.

Thomas A. Parnell, Jr., instructor, University of Wyoming.

David F. Paulsen, associate professor, Louisiana State University/New Orleans; formerly of University of Arizona.

Sophia Peterson, assistant professor, West Virginia University.

Paul E. Peterson, assistant professor, University of Chicago.

John M. Phelps, interim assistant professor, The Catholic University of America.

Charles R. Planck, assistant professor, SUNY at Buffalo; formerly of John Hopkins University (SAIS).

Nelson W. Polsby, professor, University of California/Berkeley; formerly of Wesleyan University.

Nathan S. Popkin, assistant professor, Simon Fraser University, British Columbia, September 
1967; formerly visiting assistant professor, Simon Fraser.

G. Bingham Powell, assistant professor, University of California/Berkeley.

Douglas W. RAE, assistant professor, Yale University; formerly of Syracuse University.

Alan ReED, assistant professor, University of Nebraska.

EDWARD F. Renwick, assistant professor, Louisiana State University/New Orleans; formerly of University of Southwestern Louisiana.

RANDAll B. RipLey, associate professor, ohio State University; formerly of the Brookings Institution.

IRA S. RoHTER, lecturer, University of California/Berkeley, 1967-68.

George K. Romoser, associate professor, University of New Hampshire; formerly of Connecticut College.

Lestie J. Roos, JR., assistant professor, Brandeis University; formerly of M.I.T.

Richatd N. Rosecrance, professor, University of California/Berkeley; formerly of UCLA.

Jon Rosenbaum, instructor, Wellesley College.

Albent H. Rosenthal, professor, University of New Mexico.

Stephen Rozman, instructor, University of Nebraska.

Rober' Russeld, assistant professor, Wisconsin State University/Oshkosh; formerly of Bowdoin College.

BRENT M. RUTHERFord, assistant professor, SUNY at Buffalo; formerly of Northwestern University.

Philippe Schmitrer, assistant professor, University of Chicago.

Glendon Schubert, William Rand Kenan, Jr. professor, University of North Carolina; formerly of Michigan State University.

Paul Seaburr, professor, University of California/Berkeley; formerly of University of California/Santa Cruz.

Donald Searing, assistant professor, University of North Carolina; formerly of Washington University.

Morley Segal, associate professor, School of Government and Public Administration, The American University.
JAMES C. Sco'T, assistant professor, University of Wisconsin.

Robert S. Sharlet, assistant professor, Union College; formerly of University of Missouri.

Henry Shue, joint appointment as assistant professor, political science and philosophy, University of North Carolina.

Sara M. Shumer, assistant professor, Haverford College; formerly of University of California/Berkeley.

RANDOLPh M. Stverson, acting assistant professor, University of California/Riverside.

BruCe L. R. SMith, associate professor, Columbia University.

Roger M. SMith, assistant professor, University of Michigan; formerly of University of Washington.

Steven Spiegel, assistant professor, University of California/Los Angeles.

William C. Spragens, assistant professor, Wisconsin State University/Oshkosh; formerly of Millikin University.

George Stambuk, professor, George Washington University program, Naval War College Center, New Port, Rhode Island.

Herbert W. Stephens, assistant professor, University of Arkansas, September 1967; formerly of Florida State University.

Stephen V. STEPhens, assistant professor, University of California/Los Angeles, September 1967.

Dennis C. Storer, lecturer, University of Colorado, September 1967.

John R. Swanson, assistant professor, University of Missouri.

RICHaRd TAYLOR, professor, Kent State University; formerly of Coe College.

PaUl A. Tharp, instructor, University of Oklahoma.

Elias S. Thermos, instructor, Roosevelt University.

Dennis Thомpson, lecturer, University of Arizona; formerly of University of California /Santa Barbara.

Thomas Landon Thorson, associate professor, University of Toronto; formerly of the University of Wisconsin. 
GLen E. Thurow, assistant professor, SUNY at Buffalo; formerly of Bucknell University.

JAMES W. TodD, assistant professor, University of Washington; formerly of University of Iowa.

Taketsugu Tsurutani, assistant professor, University of Maine.

William P. Tucker, professor, Texas Technological College.

Edward R. Tunte, assistant professor, Princeton; formerly of Yale.

Franklin Tugwell, Pomona College, February $1,1968$.

Paul W. Van der Veur, professor and director Southeast Asia Studies Center, Ohio University; formerly of Northern Illinois University.

Herbert Weisberg, assistant professor, University of Michigan.

Donald Wilhelm, professor, Kent State University; spring 1968 .

T. Alden Williams, associate professor, Kansas State University; formerly of University of Denver.

Richard Wilson, lecturer, Princeton.

DeIL Wright, professor, University of North Carolina; formerly of University of Iowa.

Sherman Wyman, assistant professor, University of Denver.

RODGER D. Yeager, assistant professor, West Virginia University.

RIChard M. YEarwood, associate professor, Center for Urban and Regional Studies, Virginia Tech.; formerly executive director, Asheville Metropolitan Planning Board.

Oran R. Young, assistant professor and bicentennial preceptor, Princeton; formerly of Center of International Studies, Princeton.

Elliot Z ZASHIN, assistant professor, University of Texas; formerly of University of California /Berkeley.

Susan G. Zielenbach, instructor, Trinity College, Washington, D.C.

Kenneth C. Zimmerman, assistant professor, University of Maine.

Marvin Zonis, assistant professor, University of Chicago; formerly of MIT.

\section{Visiting Appointments}

Philip A вRams, Cambridge University: professor, M.I.T., 1967-68.

A. DoaK Barnett, Columbia University: professor, M.I.T., 1967-68.

Glenn E. Brooks, Colorado College: professor, University College, Nairobi, Kenya, 1967-68.

George E. G. Cathin, London, lecturer, University of Illinois, fall, 1967.

Peter Ping-Chir Cheng, reappointed professor, University of Nebraska, 1967-68.

Alan F. Davies, University of Melbourne: professor, University of Alberta, 1967-68.

RAYMond H. DAwson, University of North Carolina: professor and research associate, Institute for War and Peace Studies, Columbia University, 1967-68.

Olcotт Demina, former Ambassador to Uganda and currently Senior State Fellow in Residence: professor, University of North Carolina, 1966-67.

LyLe A. Downing, formerly of Emory University: assistant professor, Louisiana State University.

Joseph DUnner, Yeshiva University: professor, Research Institute of Political Science and European Problems, University of Cologne, summer, 1967.

Ben Franklin, Chico State College: professor, Sacramento State College, fall, 1967.

Anne Freedman, associate professor, Roosevelt University.

Richard M. Fulton, instructor, Western Reserve University.

Michael P. Gehlen, Purdue University: associate professor, University of California at Berkeley.

Harvey Glickman, Haverford College: professor and Fulbright lecturer, Hebrew University Jerusalem, 1967-68.

Rudolph Gomez, Colorado College: FulbrightHayes lecturer, Catholic University, Lima, Peru, April-December, 1967.

Kenneth W. Grundy, Western Reserve University: professor, Makerere University College, University of East Africa, Kampala, Uganda, 1967-68.

Darrell P. Hammer, Indiana University: professor, Columbia, spring 1967. 
Donald Hancock, University of Texas: assistant professor, Columbia, summer, 1967.

Milton Новвs, Indiana University: lecturer, University of Illinois, 1967-68.

Charles Judah, University of New Mexico: professor, Sacramento State College, 1967-68.

Arthur Kalleberg, professor, University of Minnesota, 1967-68.

SANFord A. LAKofF, SUNY at Stony Brook: professor, University of Toronto, 1967-68.

Remy Leveau, Institut d'Etudes Politiques de Paris: associate professor, University of Michigan, 1967-68.

Klaus Liepelt, DATUM, Germany: lecturer, University of Michigan summer, 1967.

Vernon McGee, formerly director of the Legislative Budget Bureau of the State of Texas: lecturer, University of Texas, spring, 1967.

VAL G. Mixon, instructor, Emory University.

Ray Morey, Denison University: Ohio State University, summer, 1967.

Mark Neuwald, University of New Mexico: associate professor, University of California at Berkeley, summer, 1967.

KARL O'Lessker, professor, University of Illinois, Urbana, 1967-68.

Felix E. Oppenherm, University of Massachusetts: professor, Columbia University, autumn, 1967.

Charles Parrish, University of Texas: senior lecturer, University of Essex, Colchester, England, 1967-68.

Stefano A. Passigli, University of Padua, Italy : associate professor, University of Michigan, fall, 1967 .

William Ritchie, Western State University (Michigan): associate professor, University of Texas, spring, 1967.

Bernard Schaffer, University of Sussex, England: professor, Cornell University, fall term, 1967.

Richard F. Starr, Emory University: professor, National War College, 1967-68.

Hans B. Thorelit, Indiana University; professor, University of South Africa, summer, 1967.

Herbert Tingsten, George A. Miller professor, University of Illinois, Urbana, fall, 1967.
IRWIN L. WHITE, assistant professor, University of Arizona, 1967-68.

Jerzy Wiatr, Polish Academy of Sciences, Warsaw: professor, University of Michigan, summer, 1967.

FrederICK M. WIRT, Dension University: professor, Uniiversity of California, 1967-68.

\section{Promotions (with new rank)}

Charles W. Anderson, University of Wisconsin; professor.

Donald L. M. Blackmer, Massachusetts Institute of Technology: associate professor.

Bohdan R. Bocturkiw, University of Alberta, Canada: professor.

Frank Bonilla, Massachusettis Institute of Technology: professor.

Robert B. Callahan, California State College/Los Angeles: professor.

C. W. Cassinelit, University of Washington: full professor.

David Chang, Wisconsin State University /Oshkosh: professor.

Jorotpaul Chatnhuri, University of South Dakota: associate professor.

Dorothy I. Chine, University of New Mexico: professor.

Frank T. Colon, Lehigh University: associate professor.

Michael N. Danielson, Princeton University: associate professor.

Arthur Darken, Wisconsin State University /Oshkosh: professor.

Jameson W. Dorg, Princeton University: associate professor.

Alex Edermane, University of Nebraska: professor.

John D. Esseks, Wisconsin State University /Oshkosh: assistant professor.

Leonard J. Fein, Massachusetts Institute of Technology: associate professor.

Jeff Fishel, The American University: assistant professor.

Richard Flatham, University of Chicago: associate professor.

Donald M. Freeman, University of Arizona: associate professor. 
Felix V. Gaqliano, Purdue University: assistant professor.

Robert S. Getz, Kent State University: associate professor.

Royal C. Gilkey, West Virginia University: professor.

Alba M. Gitlespie, Humboldt State College: associate professor.

Robert G. Gilpin, Jr., Princeton University: associate professor.

BetTy GLAD, University of Illinois: associate professor.

Emilia L. Govan, Trinity College: assistant professor.

Rev. Francis J. Grogan, S. J., St. Peter's College: associate professor.

Jozl B. Grossman, University of Wisconsin: associate professor.

Manfred Halpern, Princeton University: professor.

Royce Hanson, American University: professor.

Ervin C. Hargrove, Brown University: associate professor.

Kenneth Kofmeht, Purdue University: professor.

Fred Iklé, Massachusetts Institute of Technology: professor.

Warren F. Ilchman, University of California /Berkeley: associate professor.

HERBERT $J_{A C O B}$, University of Wisconsin: professor.

James H. Lare, Occidental College: professor.

Charles S. Liebman, Yeshiva College: associate professor.

N. O. Linton, University of Alberta: associate professor.

JoHN P. LoveLL, Indiana University: associate professor.

Robert E. MacArthur, Vassar College: assistant professor.

David S. Mcleluan, University of California at Riverside: professor.

Louis H. Masotri, Western Reserve University: associate professor.
Joseph Nyomarkay, University of Southern California: associate professor.

William Melnicoe, Sacramento State College: professor.

Husain Mustafa, Kent State University: associate professor.

Bruce F. Norton, The American University: assistant professor.

Begman Patterson, Kent State University: assistant professor.

T. C. Pocklington, University of Alberta: associate professor.

Mojmir Povolny, Lawrence University: professor.

Nathaniel S. Preston, The American University: professor.

George W. Rice, West Virginia University: associate professor.

JoHN B. RICHARD, University of Wyoming: associate professor.

Gerald Rigby, University of Southern California: associate professor.

Peter H. Rohn, University of Washington: associate professor.

Carl G. Rosberg, University of California /Berkeley: professor.

Warner R. Schilling, Columbia University: professor.

Walter S. Schoenberger, University of Maine: professor.

Allen A. Sprtz, Washington State University: associate professor.

John D. Sprague, Washington University: associate professor.

James Watson, San Jose State College: professor.

\section{Administrative Appointments}

LUCIUS J. BARKER: professor and joint appointment as a research associate in the Chancellor's office, University of Illinois/Urbana, September 1, 1967.

William J. Block: head, North Carolina State College/Raleigh.

Bernard C. Borning: acting head, University of Idaho, 1967-68. 
Robert E. Cecile: chairman, Wright State Campus of Miami and Ohio State Universities.

James B. Christoph: professor and chairman, Indiana University, formerly of Ohio State University.

JAmes T. Crown: chairman, University College, New York University.

ATHERN P. DAGgetT : acting president, Bowdoin College, 1967-68.

Frank C. Darling: head, DePauw University; formerly of University of Colorado.

Richard R. Dohm, University of Missouri, has been named director of the university's Governmental Affairs Program.

Joseph C. Doherty: professor and chairman, University of Scranton, September, 1967; formerly of Saint Leo College, Florida.

Robert S. Frimduan: acting director of the Institute for Public Administration, University of Michigan.

William R. Gable: professor and director, Institute of Public Administration, Arizona State University/Tempe; formerly of University of Michigan.

JAY S. Goodman: chairman, Wheaton College.

Rev. Francis J. Gongan, S. J.: chairman of the newly created Department of Political Science, St. Peter's College.

HARRY S. HALL: associate professor and chairman, California State College/Los Angeles.

Robert HolT: director, Center for Comparative Research in Technology and Social Change, University of Minnesota.

Robert W. HATterY: assistant dean in the Division of University Extension at Indiana University. This is an addition to his duties as director of the Bureau of Public Discussion.

Lynwood M. Holland: head, Texas Technological College; formerly of Emory University.

J. Terry Iverson: academic coordinator international affairs, University of Illinois Extension Division; joint appointment in political science.

Edward G. Janosik: chairman, State University College, Geneseo, New York; formerly University of Pennsylvania.

MaLColm H. KerR: chairman, University of California/Los Angeles. July 1.
Eugene C. Lee: director, Institute of Governmental Studies, University of California/Berkeley.

JoHN M. H. LindBeck: senior lecturer in government and director of the East Asian Institute Columbia University.

Eugene A. Mawhinner: head, University of Maine.

Grant McConnelu: chairman, University of Chicago.

Gerald R. McDaniel: chairman, Sacramento State College.

R. Judson MrtchelL: assistant professor, Emory University.

RoBert Mortimer: assistant professor and chairman, Haverford College.

Robert Pealy: professor and director of the Bureau of Governmental Research and Service, University of Washington.

Richard Powers: professor and director, The American University's Center for Technology and Administration.

Robert Presthus: professor and chairman, York University, Toronto.

Merton L. Reichler: assistant to academic vice-president, SUNY at Stony Brook, July 1, 1967.

JAMES A. RoBINson: professor and director, Mershon Center for Education in National Security, Ohio State University.

Marshall D. Schulman: professor and director of the Russian Institute, Columbia University.

Cart J. Schneider: professor and chairman, Kirkland College/Clinton, New York; formerly of the University of Nebraska.

Howard Wriggins: professor and director of the Southern Asian Institute, Columbia University; formerly of the U.S. State Department.

\section{Retirements}

Preston W. Ensall, has retired as professor and head of the department at North Carolina State University at Raleigh.

MARTIN L. FAUST has retired from active teaching at the University of Missouri. He has been designated professor emeritus. 
Nerl F. Garver, University of Illinois, Urbana, retired from the department in August, 1967.

Charles B. Hagan, University of Illinois, retired in June, 1967.

Charles B. Judah, University of New Mexico, retired on June 30, 1967 after twenty years of service.

James K. Pollock, Murfin Professor of Political Science, University of Michigan, retired in June.
Ror E. Sherman, has retired from the University of Akron after 38 years of service. He will become a professor at the College of Emporia in September, 1967.

Cart B. Swisher, Johns Hopkins University, retired in June.

RALPH M. WADE, has retired as professor of political science at the University of Wyoming.

Francis G. Wilson, retired in June from the University of Illinois. He will teach at Long Island University, Greenvale, N.Y.

\section{IN MEMORIAM}

Carl L. Heyerdahl, Professor Emeritus of Political Science, Purdue University, died in Yuma, Arizona, on December 30, 1966. His first appointment at Purdue University was as instructor of history and economics in 1928. He advanced through the ranks of assistant and associate professor and in March of 1966, the Board of Trustees bestowed the title of Professor Emeritus of Political Science upon him. During his final years on the faculty he served in a variety of positions at the departmental and school level. In these assignments his stability and strength of character were particularly prized by younger colleagues who sought him out for counsel on both academic and personal matters.-PuRduE UNIVERSITY,

John Halvor Leek, David Ross Boyd professor emeritus of government, University of Oklahoma, died February 14, 1967, at the age of 70 , following a long illness. He is survived by his sister, Norma Leek, 478 College, Norman, Oklahoma.

A native of Batavia, Illinois, Professor Leek received his advanced training at James Millikin University, A.B., 1920; the University of Illinois, A.M., 1921; and the University of Pennsylvania, Ph.D., 1925. His teaching career subsequently was devoted to the University of Oklahoma from the time of his appointment as assistant professor of government in $\mathbf{1 9 2 5}$.

He will always be affectionately remembered and revered by his students and colleagues as a superb teacher-rigorous, systematic, and interesting. He had broad cultural interests, which unobtrusively enriched his contribution to countless students of his classes in American National Government, American Constitutional Law, and Government and Labor. In addition to his fields of specialization, he always maintained a specialized interest and appreciation in the fields of American biography and political history, and music. $\mathrm{He}$ was an activist in the civil rights field.
In 1949, the evaluation of Professor Leek as a teacher, manifest by the actions of students and colleagues, was recognized by his university, with his appointment as David Ross Boyd professor-a distinguished professorship, honoring vigorous performance and leadership in teaching and guidance of students.

His published works included: Legislative Reference Work, A Comparative Study, 1925; Principles and Functions of Government in the United States (co-author), 1948; and Government and Labor in the United States, 1952, as well as articles in professional journals, and literally hundred of book reviews in local newspapers.-JosepH C. PraY.

Linden Alfred Mander, Professor of Political Science at the University of Washington died on April 2, 1967 at the age of 70, two months short of his scheduled retirement in June. Professor Mander arrived in Seattle from his native Australia in 1928, and served the University with unmatched devotion to both his students and the civic community from that time until his death.

His contribution to the interests of the "civic community" deserves separate mention because his involvement in what has been called "continuing education" both antedated his connection with the University and would have postdated it had he lived to fulfill arrangements already entered into before his death. He was active in the Worker's Education movement of the Twenties while still a student at Adelaide, and he would have continued his highly successful University Conversation series on TV appearances on local channel 9 had he lived beyond his allotted three score and ten.

Mander's principal teaching interest was international organization, a subject writ large in portent within the span of his active career by the institution of two ostensible Parliaments of Mankind. And he responded to the intellectual challenge of these events with a combination of opti- 